\title{
THE SCOPE OF REAL PROPERTY FORFEITURE FOR DRUG-RELATED GRIMES \\ UNDER THE COMPREHENSIVE FORFEITURE ACT
}

\author{
Sean D. Smithi
}

Congress passed the Comprehensive Drug Abuse Prevention and Control Act of $1970^{1}$ in response to the "growing menace of drug abuse in the United States."2 As initially enacted, application of its criminal forfeiture provision was restricted to defendants convicted of participating in continuing criminal enterprises ("GCE") under 21 U.S.G. $\S 848 .^{3}$ The initial success of the forfeiture provision in combating narcotics trafficking was limited. ${ }^{4}$ The statute was subsequently amended by the Comprehensive Forfeiture Act of $1984^{\circ}$ to impose forfeiture under 21 U.S.C. $\S 853^{\circ}$ upon all defendants convicted of drug felonies. ${ }^{7}$

This Comment considers the use of section 853 in the forfeiture of real property. A drug trafficker can make use of real property in his criminal activities, but only a portion of any one parcel of real property

† B.A. 1984, Swarthmore College; J.D. Candidate 1989, University of Pennsylvania.

1 Pub. L. No. 91-513, 84 Stat. 1236 (also known as the Drug Control Act and the Controlled Substances Act).

${ }^{2}$ H.R. ReP. No. 1444, 91st Cong., 2d Sess., pt. 1, at 1, reprinted in 1970 U.S. Code Cong. \& Admin. News 4566, 4567 [hereinafter H.R. REP. No. 1444].

${ }^{3}$ For the text of this provision, see infra note 11 . "Continuing criminal enterprise" is defined in 21 U.S.C. § 848(d) (Supp. IV 1986), formerly 21 U.S.C. § 848(b), as follows:

[A] person is engaged in a continuing criminal enterprise if-

(1) he violates any provision of this subchapter or subchapter II of this

chapter the punishment for which is a felony, and

(2) such violation is a part of a continuing series of violations of this subchapter or subchapter II of this chapter-

(A) which are undertaken by such person in concert with five or more other persons with respect to whom such person occupies a position of organizer, a supervisory position, or any other position of management, and

(B) from which such person obtains substantial income or sources.

- See S. REP. No. 225, 98th Cong., 1st Sess. 191, reprinted in 1984 U.S. CoDE Cong. \& Admin. News 3182, 3374 [hereinafter S. ReP. No. 225].

s Pub. L. No. 98-473, §§ 301-309, 98 Stat. 1837, 2040-57.

- For the text of this provision, see infra note 22 .

7 See United States v. Nichols, 841 F.2d 1485, 1488 (10th Cir. 1988); infra note 22; infra note 80 and accompanying text. 
need be directly involved in the commission of a drug-related felony. Furthermore, real property can be both valuable and extensive. Consequently, courts have differed when deciding whether forfeiture should apply to the whole of a parcel of property or to only those portions directly involved in the offense. ${ }^{8}$

This Comment argues that, based on the language of section 853 and its predecessor, section 848 , their legislative history, policy considerations, and comparison with similar forfeiture statutes, entire parcels of real property should be forfeited, even when only a portion of the property was used directly in committing the offense. Part I examines the cases interpreting this aspect of these forfeiture provisions and discusses the language and legislative history of the provisions. Part II compares these forfeiture provisions with an analogous Racketeer Influenced and Corrupt Organizations ("RICO") provision, while Part III compares them to section $881(\mathrm{a})(7)$, the real property subsection of the civil forfeiture provision of the Comprehensive Drug Abuse Prevention and Control Act. ${ }^{10}$ Finally, Part IV analyzes the eighth amendment implications of an expansive reading of section 853 as applied to real property.

\section{Real Property Forfeiture for Drug Felonies}

\section{A. Presenting the Problem}

The Comprehensive Drug Abuse Prevention and Control Act of 1970 provided for the forfeiture of real property "affording a source of influence over" a continuing criminal enterprise. ${ }^{11}$ In United States $v$. McKeithen, ${ }^{12}$ the Second Circuit interpreted this statute to require for-

8 Compare United States v. Littlefield, 821 F.2d 1365, 1367 (9th Cir. 1987) (holding that all of a 40-acre parcel of land was subject to forfeiture under 21 U.S.C. $\S 853$, although only a portion of it had been used for the drug offense) with United States v. McKeithen, 822 F.2d 310, 313, 315 (2d Cir. 1987) (holding that because only the building used in the drug offense was subject to forfeiture under 21 U.S.C. $§ 848$, the defendant was entitled to the proceeds from the government's sale of the rest of the property).

9 Organized Crime Control Act of 1970, Pub. L. No. 91-452, $\S \S 901-04,84$ Stat. 922, 941-48.

10 See 21 U.S.C. § 881 (1982 \& Supp. IV 1986).

11 Until amended in 1984, see infra note 22 and accompanying text, section $848(a)(2)$ read in relevant part:

(2) Any person who is convicted under paragraph (1) of engaging in a continuing criminal enterprise shall forfeit to the United States-

- .

(B) any of his interest in, claim against, or property or contractual rights of any kind affording a source of influence over, such enterprise.

12822 F.2d 310 (2d Cir. 1987). 
feiture of only those portions of a parcel of real property that actually were connected with, or directly used in, the defendant's criminal enterprise. ${ }^{13}$

McKeithen pleaded.guilty to conducting a continuing criminal enterprise relating to cocaine and heroin distribution in violation of 21 U.S.C. $\$ 848(a)(1) .{ }^{14}$ The forfeiture portion of the case was subsequently tried under section 848(a)(2); at stake were three parcels of land owned by the defendant. ${ }^{15}$ The jury returned a special verdict finding that two of the parcels were entirely subject to the forfeiture provisions of section 848 (a)(2) because they "afforded defendant a source of influence over his criminal enterprise." ${ }^{\prime 6}$ The jury found, however, that only forty-three percent of the third parcel afforded such an influence. ${ }^{17}$ This parcel "contained two buildings, one a two-family house and the other a six-family apartment dwelling. ... [D]efendant's narcotics enterprise operated out of the two-family house; the six-apartment unit, on the other hand, was not engaged in the narcotics enterprise."18 The district court ruled, however, that McKeithen had to forfeit his entire interest in all three properties; an expert in real estate conveyancing had testified that subdivision of the third parcel was legally impossible, which apparently swayed the court. ${ }^{19}$ The Second Circuit disagreed with this ruling, reversed it, and remanded the case for entry of judgment according to the jury's verdict. ${ }^{20}$ The court, interpreting section $848(\mathrm{a})(2)(\mathrm{B})$, was

persuaded that the statutory language "any ... property . . . affording a source of influence over" a criminal enterprise means, at least in the context of realty subject to forfeiture, that specific portion of a defendant's property affording a source of influence over the enterprise. In other words, "to forfeit property a connection must be shown with that which offends."21

13 See id. at 315 .

14 See id. at 311. Section 848(a)(1) set forth the penalties to be imposed for CCE convictions, while section $848(a)(2)$ dealt specifically with the forfeiture provisions.

${ }^{15}$ See id. at 311-12.

16 Id. at 312.

17 See id.

18 Id.

18 See id. at $312-13$.

20 See id. at 312. The court quickly disposed of the district court's reasoning, pointing out that the government could effectively subdivide the defendant's property by retaining an appropriate portion of the proceeds from the sale of the property; it also disapproved of the notion of federal criminal forfeiture turning on local property law. See id. at 313.

21 Id. at 315 (citation omitted) (quoting United States v. About 151.682 Acres of 
In 1984, section 848(a)(2) was amended and relocated to section 853(a). ${ }^{22}$ Interpreting section 853(a)(2), the Ninth Circuit in United States $v$. Littlefield ${ }^{23}$ disagreed with the Second Circuit's interpretation of the limits of real property forfeiture.

Littlefield was convicted of "cultivating and possessing with intent to distribute over 700 marijuana plants" that he was growing on a forty-acre parcel of property. ${ }^{24}$ Pursuant to section 853(a), the government sought forfeiture of all of Littlefield's interest in the land on which the marijuana had been grown. ${ }^{25}$ At the district court level, the case was known as United States v. Anderson ("Anderson $I^{\prime \prime)}{ }^{26}$ In Anderson $I$, the court reached the same conclusion under section 853 as would the Second Circuit in McKeithen under section 848; indeed, its opinion was the principal support for McKeithen. ${ }^{27}$ The district court concluded that

based upon a plain reading of the statute at issue here, upon the relevant legislative history, upon the rule of lenity in construction of criminal statutes, and upon the aforemen-

Land, 99 F.2d 716, 720 (7th Cir. 1938)).

${ }_{22}$ See 21 U.S.C. $\S 853$ (a) (Supp. IV 1986). The Comprehensive Forfeiture Act of 1984, also known as the Comprehensive Crime Control Act, both amended the forfeiture provision and moved it in order to create "a new criminal forfeiture statute that would be applicable in all felony drug cases." S. REP. No. 225, supra note 4, at 198, reprinted in 1984 U.S. CODE CONG. \& ADMIN. NewS at 3381; see also id. at 209, reprinted in 1984 U.S. Code Cong. \& ADMIN. News at 3392 (noting that the new forfeiture provision would "be applicable to all felony offenses under the Act").

21 U.S.C. $\$ 853(\mathrm{a})$, covering property subject to criminal forfeiture, reads in relevant part:

Any person convicted of a violation of this subchapter or subchapter II of this chapter punishable by imprisonment for more than one year shall forfeit to the United States, irrespective of any provision of State law-

(2) any of the person's property used, or intended to be used, in any manner or part, to commit, or to facilitate the commission of, such violation; and

(3) in the case of a person convicted of engaging in a continuing criminal enterprise in violation of section 848 of this title, the person shall forfeit, in addition to any property described in paragraph (1) or (2), any of his interest in, claims against, and property or contractual rights affording a source of control over, the continuing criminal enterprise.

Section 853(a)(2) encompasses property used to facilitate drug felonies, which can be read at least as broadly as "affording an influence over." See infra notes 136-56 and accompanying text.

${ }^{2 s} 821$ F.2d 1365 (9th Cir. 1987).

24 Id. at 1366 .

25 See id.

${ }^{28} 637$ F. Supp. 632 (N.D. Cal. 1986).

${ }^{27}$ See McKeithen, 822 F.2d at 314. 
tioned constitutional considerations, this Court finds that under 21 U.S.G. $\S 853(\mathrm{a})(1)$ and (2), . . u upon conviction of a felony drug offense, only those portions of defendants' property . . . "used or intended to be used to commit or facilitate the commission" of a drug felony, shall be subject to forfeiture. $^{28}$

The Ninth Circuit reversed, arguing that "Congress plainly provided for forfeiture of property even where only a portion of it was used for the prohibited purposes."29

\section{B. Interpretation of the Statutes}

The Second Circuit framed the issue in McKeithen as "whether the CCE provision involved here permits proportional forfeiture."30 The court noted that the language of the statute, providing for forfeiture of "any" property affording a source of influence over a CCE, was ambiguous on this point. ${ }^{31}$ The court concluded, however, that in section $848(a)(2)(B)$, "[t]he word 'property' is modified by the phrase 'affording a source of influence over,' which renders reasonable defendant's proportional forfeiture argument," even though it agreed "that Congress could have used language which would more specifically compel a ruling in defendant's favor on the point at issue." ${ }^{\text {"32 }}$ The $M c K$ eithen court cited two general principles of statutory construction in support of its decision. First, noting that all laws should be construed to avoid absurd consequences, the court determined that proportional forfeiture was "consistent with the legislative aims of deterrence, and destruction of economic power bases, of criminal profiteers," while "the government's position . . . could lead to results far more bizarre than the one presented here, and there would appear to be no limiting principle available once the government's argument is accepted."s3 The court also argued that criminal statutes demand strict construction, with any ambiguities resolved in favor of lenity. ${ }^{34}$

The McKeithen analysis of section 848 is unsatisfactory. First, al-

28 Anderson I, 637 F. Supp. at 637.

29 Littlefield, 821 F.2d at 1367.

so McKeithen, 822 F.2d at 313.

31 See id.

32 Id. at 315.

ss Id.

34 See id. at 315 (" As a criminal statute, section 848 "must be strictly construed, and any ambiguity must be resolved in favor of lenity." " (quoting United States v. Long, 654 F.2d 911, 914 (3d Cir. 1981) (quoting United States v. Emmons, 410 U.S. 396, $411(1973))))$. 
though the phrase "any . . . property . . . affording a source of influence over[] such enterprise" does not explicitly state that entire parcels of property should be forfeited when only a portion is directly involved in the offense, the requirement that "any" such property be forfeited suggests a more expansive reading of the provision than that of the Second Gircuit. Based on the language of the statute, proportional forfeiture is certainly no more reasonable than a forfeiture of the entire parcel. The argument for a broader interpretation, moreover, has greater force in light of the statute's legislative history ${ }^{35}$ and subsequent revision. ${ }^{36}$

Second, the court's attempt to avoid "absurd" or "bizarre" consequences $^{37}$ is not logically coherent. The court, apparently in response to the possibility that vast tracts of land might be forfeited, remarked that a more expansive reading of the statute would have no limiting principle. ${ }^{38}$ Such a view does not, however, take into account that entire plots of land can be useful to drug traffickers in ways that are not immediately obvious. ${ }^{39}$ Furthermore, the logic behind the court's narrower interpretation is no less absurd than the interpretation it rejected. If forfeiture is limited to property "affording an influence over" the

ss See infra notes 67-85 and accompanying text.

se See supra note 22 and accompanying text.

37 See McKeithen, 822 F.2d at 315.

38 See id.

39 For example, larger parcels of property can make it easier to conceal illegal activities. One case that discussed this notion concerned the forfeiture of a 151-acre farm because of a distillery on the premises. The court was, however, able to side-step the issue, because the prosecutor focused on the size of the still:

It is urged that a large still, such as here found, requires a large farm to hide it, but we are not impressed with the argument that the acreage subject to be condemned can be determined by the size of the still, and certainly such cannot be held as a matter of law.

United States v. About 151.682 Acres of Land, 99 F.2d 716, 720 (7th Cir. 1938).

In Vermont, wily marijuana growers have been able to use such concealment to their advantage. " 'They are growing it in small plots and hiding it,' [a local sheriff] said. 'They plunk it all over the place.' " N.Y. Times, Oct. 25, 1987, $\S 1$, at 44, col. 4; see also N.Y. Times, Oct. 6, 1987, at A33, col. 1 ("In recent years, police helicopter spotting programs and other efforts have led growers to decentralize and grow on smaller plots.").

There is no reason to give such growers the benefit of their cleverness by requiring forfeiture of only those portions of the property on which marijuana was actually grown. "Growing of marijuana has become an increasing problem in many areas, confronting the authorities with the need to search millions of square miles of often rough terrain." N.Y. Times, Oct. 6, 1987, at A33, col. 1. If growers were allowed to keep portions of property that is ideally suited to their purposes, they would be able to resume their marijuana growing as soon as the attention of law enforcement authorities was drawn elsewhere. The same argument could be made with respect to drug laboratories, storage areas, and other aspects of the drug trade that require secrecy. 
enterprise in the narrow sense favored by the court, ${ }^{40}$ forfeiture in Littlefield might be limited to the actual holes in the ground from which the marijuana plants sprang. Alternatively, a court could choose to limit forfeiture to the land under which the plants' roots lay, the land from which flowed the water that nourished the plants, or the land that helped conceal the plants by shielding them from view. ${ }^{41}$ In short, the narrow construction favored by the Second Circuit is, when applied strictly, no less potentially absurd than requiring felons convicted of drug-related crimes to forfeit entire parcels of property. Moreover, it might be applied erratically. It also allows such felons to escape the harsh forfeitures Congress favored. ${ }^{\mathbf{4 2}}$

In McKeithen, the court might have required forfeiture of portions of the interior of the building that was the site of the narcotics enterprise; the path from the street to the building might also have been included. Of course, because the walls hid the illegal activities, they, too, could be subjected to forfeiture. The apartment building legitimately rented to tenants could also be included: it could have provided a deceptive "front" for the illegal enterprise." Although decisions could

40 The McKeithen court would require that before property could be forfeited, " 'a connection must be shown with that which offends." 822 F.2d at 315 (quoting About 151.682 Acres of Land, 99 F.2d at 720). The court required forfeiture only of that portion of the proceeds from the sale of the property that could be attributed to the sale of the building used for the operation of the drug enterprise. This connection appears to be fairly direct: something akin to actual use in the illegal activity must be shown. The McKeithen court's reliance on About 151.682 Acres of Land may have been misplaced, in any case. At least one court has distinguished the civil forfeiture statutes for distilleries, such as the one used in that case, from the current civil forfeiture statute, section 881 , on the ground that the old statutes required " a connection or relation between the farm and the distillery," while in section 881(a)(7) Congress used clearly broader language demanding forfeiture of whole parcels of property. United States v. Reynolds, 43 Crim. L. Rep. (BNA) 2463, 2464 (4th Cir. Sept. 14, 1988) (quoting About 151.682 Acres of Land, 99 F.2d at 720 (emphasis added by Reynolds court)).

41 Developers of a computer program to help locate marijuana farms determined that "marijuana plots in the United States tend to be hidden on the south side of groves of trees." N.Y. Times, Oct. 6, 1987, at A33, col. 2. Although the trees would thus facilitate the offense, or be used in the commission of the offense, under a narrow reading of the statute they would not be subject to forfeiture.

42 See infra notes 67-85 and accompanying text.

43 For example, one newspaper account describes how, in Miami, "[f]ederal agents . . . confiscated more than three tons of cocaine hidden in hollowed-out lumber in a suburban warehouse." N.Y. Times, Nov. 19, 1987, at B11, col. 1. If this were one of several warehouses on the property, and if the property owner had been behind the scheme, the McKeithen court's approach would allow the owner to retain the other buildings, or at least the money from their sale, despite the fact that they had not only helped conceal the drug trafficking, particularly if they acted as a front in the form of a legitimate business, but also could assist in the commission of similar crimes in the future. The intent of Congress, see infra notes 67-85 and accompanying text, would be foiled unless the entire parcel of property were forfeited, thereby inflicting maximum 
be made on this proportional basis, ${ }^{44}$ it would defeat the purpose of forfeiture: to cripple the economic bases of drug traffickers. ${ }^{45}$ Congress passed tough forfeiture legislation because traditional criminal sanctions such as imprisonment and fines were proving ineffectual in deterring drug traffickers. ${ }^{46}$ A narrow interpretation would vitiate this legislation by allowing traffickers to exempt from forfeiture those portions of their property less directly connected to their crimes.

Finally, the Second Circuit's invocation of the doctrine of lenity ${ }^{47}$ might have been appropriate when the forfeiture provision was contained in section 848. Now, however, section 853(o) specifies that "[t]he provisions of this section shall be liberally construed to effectuate its remedial purposes." ${ }^{38}$ The McKeithen court ${ }^{49}$ cited Anderson $1,{ }^{50}$ the

damage on the trafficker's economic base and making it more difficult for him to resume his illegal activities.

11 For instance, in United States v. Elliot Hall Farm, 42 F. Supp. 235 (D.N.J. 1941), the court ordered forfeiture of only that portion of the farm that the government had "connected with the distillery operation". Id. at 239. The forfeited portion consisted of the private lane leading from the highway to the barnyard, the horse barn that was connected to the shed housing the still, and other sheds that contained "parts and things used in connection with the still." Id. Also ordered forfeited were the pipeline used to carry water from a brook to the still, the land "over which and through" the pipeline travelled, and the land "adjacent" to the land, horse barn and sheds. Id. This forfeiture order was not only clumsy and uncertain (how extensive is "adjacent"?), but also inflicted a minimum amount of damage on the operator of the still. While the farm owner would have had to build a new barn and sheds, and presumably would have had to leap over the narrow band of land supporting the pipe that was no longer his, a drug trafficker, facing the same restrictions and making huge sums of money, would resume operations on the same land or be able to sell the land in order to invest the money in further illegal operations. This clearly frustrates the intent of Congress. See infra notes 67-85 and accompanying text. In addition, this standard would inflict on the government a more severe burden of proof to explain how the pieces of forfeited property are connected to the crime. Congress revised the statute in 1984 to make forfeitures easier, not more difficult.

4s See infra note 71 .

48 See id.

47 "Where the intention of Congress is not clear from the act itself and reasonable minds might differ as to its intention, the court will adopt the less harsh meaning." Black's LaW DictionaRy 1196 (5th ed. 1979) (citing United States v. Callanan, 173 F. Supp. 98, 100 (E.D. Mo. 1959)); see also United States v. Anderson, 637 F. Supp. 632, 636 (N.D. Cal. 1986) (stating "that criminal statutes are to be strictly construed, and any ambiguity must be resolved in favor of the defendant").

${ }^{48}$ The Littlefield court also made this observation, see Littlefield, 821 F.2d at 1367 (citing United States v. Turkette, 452 U.S. 576, 587-88 n.10 (1981)), and the Supreme Court based its broad reading of the RICO forfeiture provision in part on an identically worded provision in the RICO statute, see Russello v. United States, 464 U.S. 16, 27 (1983) (quoting Organized Crime Control Act of 1970, Pub. L. No. 91$452, \S 904(\mathrm{a}), 84$ Stat. 922,947$)$. That the section $853(\mathrm{o})$ provision is exceptional, and not to be dismissed lightly, is apparent from the Supreme Court's remark, in its discussion of the analogous RICO provision, that "[s]o far as we have been made aware, this is the only substantive federal criminal statute that contains such a directive." Id.

49 See McKeithen, 822 F.2d at 314.

so 637 F. Supp. 632 (N.D. Cal. 1986). 
district court opinion reversed in Littlefield, as analogous precedent. In Anderson $I$, the district court concluded that section $853(\mathrm{a})(2),{ }^{\mathbf{S 1}}$ the successor to section $848(a)(2)$, required that "only those portions of defendants' property . . . 'used or intended to be used to commit or facilitate the commission' of a drug felony, shall be subject to forfeiture." The district court noted that its decision was "based upon a plain reading of the statute at issue here, upon the relevant legislative history, upon the rule of lenity in construction of criminal statutes, and upon .. . constitutional considerations."

The "plain reading of the statute at issue" in Anderson $I$ was based upon a narrow interpretation that led the court, with circular logic, to "read the words of $\S 853(\mathrm{a})(2)$, 'any of the person's property used,' to mean what they say." "'st After arguing that the civil forfeiture provision, 21 U.S.C. $§ 881(\mathrm{a})(7)$, was entirely distinct from section $853,{ }^{\text {b5 }}$ the court argued that section 881's different language, mandating forfeiture of "the whole of any lot or tract of land used," further indicated that section $853(\mathrm{a})(2)$ permitted only proportional forfeiture. ${ }^{88}$

The Littlefield court's analysis of the statutory language rejected both the Anderson I court's and the defendant's arguments that the forfeiture provision "should be construed to authorize forfeiture of only that portion of the parcel used to cultivate the marijuana." Ins Instead, the Ninth Circuit stated that

[b]y specifying that property is subject to forfeiture if it was used "in any manner or part" to commit or facilitate a drug offense, Congress plainly provided for forfeiture of property even where only a portion of it was used for the prohibited

s1 21 U.S.C. $\S 853($ a)(2) (Supp. IV 1986); see also supra note 22 (discussing the 1984 amendments to the Drug Control Act).

${ }^{82}$ Anderson I, 637 F. Supp. at 637 (paraphrasing 21 U.S.C. § 853(a) (Supp. IV 1986)); see also McKeithen, 822 F.2d at 314 (stating that the Anderson I court had agreed with the defendants' contention that $853(\mathrm{a})(2)$ required forfeiture " of only that portion of any real property that was used to commit or facilitate the commission' of the crime charged" (quoting Anderson 1, 637 F. Supp. at 635)).

ss Anderson 1, 637 F. Supp. at 637; see also McKeithen, 822 F.2d at 314 ("The court was not aided to any great extent by the relevant legislative history, but nevertheless agreed with the defendants based on the statute's plain language, analogous case law and constitutional considerations.").

s4 Anderson I, 637 F. Supp. at 636.

so See id. at 635-36. But see infra notes 84 \& 122-24 and accompanying text (discussing Congress's intention that sections 853 and 881 command the same forfeiture).

so See Anderson I, 637 F. Supp. at 636 (stating that Congress intended to preserve the functional distinction between $\S 853(\mathrm{a})(2)$ criminal forfeiture and $\S 881(\mathrm{a})(7)$ civil forfeiture by using different language in the two provisions).

${ }^{87}$ Littlefield, 821 F.2d at 1366. 
purposes: A contrary reading would render meaningless the words "in any manner or part . . . ."

The court also stated that the rule of lenity had been overridden by " $a$ clear congressional directive to the contrary," because Congress had directed that the statute be given a liberal construction. ${ }^{59}$

Finally, the court compared section 853 with the civil forfeiture provision contained in section $881 .^{60}$ The court rejected Littlefield's argument that the language of section 881(a)(7) mandating forfeiture of "the whole of any lot or tract of land and any appurtenances" would, under the court's interpretation, be superfluous. ${ }^{61}$ Because section 881 also contains the phrase "in any manner or part," the court argued that any construction would necessarily render some language in one of the sections superfluous, but that the redundancy in section 881 was "the easiest to understand and accept," for, although section 853 deals with property in general, section 881 (a)(7) deals solely with real property, so that the "lawmakers may simply have thrown in the legalistic phrase 'including any right, title, and interest in the whole of any lot of [sic] tract,' so commonly used when dealing with real property, in an abundance of caution."

Although the Second Circuit, in McKeithen, had pointed to Anderson $I$ as providing support for its position, the Littlefield court took advantage of the evolution of the forfeiture provision to demonstrate the error of the McKeithen interpretation. Section 853(a)(3) contains language similar to section $848(\mathrm{a})(2)(\mathrm{B})$, referring to property "affording a source of control over[] the continuing criminal enterprise," but Little-

${ }^{88}$ Id. at 1367 (quoting 21 U.S.C. $\S 853(\mathrm{a})$ (2) (Supp. III 1985)).

s9 Id. (quoting 21 U.S.C. $\$$ 853(o) (Supp. III 1985) (" "The provisions of [section 853] shall be liberally construed to effectuate its remedial purposes." ")) (citing United States v. Turkette, 452 U.S. 576, 587-88 n.10 (1981)).

60 21 U.S.C. $\S 881(\mathrm{a})(7)$ (Supp. IV 1986) provides:

(a) The following shall be subject to forfeiture to the United States and no property right shall exist in them:

(7) All real property, including any right, title, and interest in the whole of any lot or tract of land and any appurtenances or improvements, which is used, or intended to be used, in any manner or part, to commit, or to facilitate the commission of, a violation of this subchapter punishable by more than one year's imprisonment, except that no property shall be forfeited under this paragraph, to the extent of an interest of an owner, by reason of any act or omission established by that owner to have been committed or omitted without the knowledge or consent of that owner.

Id. For a discussion of the broad scope of section 881 forfeiture and how it can be analogized to section 853 forfeiture, see infra notes 119-56 and accompanying text. 1986)).

Si See Littlefield, 821 F.2d at 1367 (quoting 21 U.S.C. § 881(a)(7) (Supp. IV

${ }^{62} I d$. 
field turned on the new section 853(a)(2), which requires forfeiture of "any . . . property used ... in any manner or part, to commit, or to facilitate the commission" of a drug offense. ${ }^{63}$ The Anderson I court's analysis ignored the clause "in any manner or part." cuit's view that the phrase "property used . . . in any . . . part" requires forfeiture of an entire parcel of real property makes a great deal more sense than the interpretations offered by the district court in $A n$ derson $I$ and the Second Circuit in McKeithen ${ }^{65}$ A determined court might still, however, read section 853 as requiring only the forfeiture of that part of the property used directly to commit a drug-related offense. A court relying on such a reading and employing a narrow view of "facilitate" could still order only the proportional forfeiture of property.

Similarly, while the Ninth Circuit's comparison of the language of sections 853 and 881 also makes a great deal of sense, it is not impervious to attack. The court's explanation that the potentially superfluous language of section 881 (a)(7) is due to that section's exclusive concern with real property is more logical than the explanation offered in $A n$ derson I, which would render superfluous the phrase "in any manner or part" in section 853(a)(2). The Littlefield analysis, however, which requires forfeiture of an entire parcel of property even if only part of that property is used directly to commit or facilitate the commission of a drug-related offense, could simply be ignored by a court such as the Second Circuit, which might be troubled by the potential consequences of such an approach.

\section{G. The Legislative History}

Neither the Second nor the Ninth Circuit ${ }^{87}$ explored the legislative history of these forfeiture provisions in any depth. This legislative history, particularly that of the 1984 amendments to the statute, reveals the congressional intent to hit drug offenders as hard as possible. Such an intent supports interpreting section 853 to require the forfeiture of whole parcels of property involved in drug offenses.

${ }^{63}$ See id. at 1366-67 (quoting 21 U.S.C. $\$ 853($ a)(2) (Supp. IV 1986)). Anderson $I$ also turned on this new provision, see Anderson $I, 637$ F. Supp. at 634, which indicates that the issue here is one of policy as much as specific language.

See supra notes 51-52 \& 54-56 and accompanying text.

es See supra notes 30-32 and accompanying text.

B For a discussion of facilitation, see infra notes 136-56 and accompanying text.

${ }^{67}$ Both the Anderson $I$ and Littlefield courts discussed the legislative history of section 853 only for purposes of comparison with section 881 , the civil forfeiture statute. See Littlefield, 821 F.2d at 1367; Anderson I, 637 F. Supp. at 635-36. A more elaborate comparison of the two statutes is undertaken in Part III of this Comment. 
The McKeithen court mentioned the legislative history of section 848 only briefly, noting that Congress intended the criminal forfeiture laws to "dissuade individuals from pursuing criminal gain and to eradicate the economic power bases making possible organized criminal and drug-related activities." 88 From this, the court concluded that "[t]he avowed legislative purpose behind section 848 furnishes us little basis ... upon which to choose between the two conflicting interpretations urged upon us." ${ }^{\text {"68 }}$

It is difficult to reconcile the Second Circuit's restrictive reading of section $848^{70}$ with its recognition that section 848 was intended to eradicate the economic power bases of drug traffickers. Broad forfeiture provisions would help prevent a convicted drug trafficker from picking up where he had left off; smaller forfeitures, on the other hand, would merely resemble costs of doing business. ${ }^{71}$

The forfeiture provision of the Comprehensive Drug Abuse Prevention and Control Act of 1970, along with the analogous provision in RICO, was the first modern criminal forfeiture provision enacted by Congress. ${ }^{72}$ Although the Comprehensive Drug Abuse Prevention and

${ }^{68}$ McKeithen, 822 F.2d at 313.

So Id. at 313-14.

70 See supra notes 30-34 and accompanying text.

71 The Chairman and Counsel of the House Subcommittee on Crime when the Comprehensive Forfeiture Act was passed in 1984 noted that "[d]rug dealers, who accumulate huge fortunes as a result of illegal drug activities, frequently perceive the financial penalties for drug dealing only as a cost of doing business." Hughes \& O'Connell, In Personam (Criminal) Forfeiture and Federal Drug Felonies: An Expansion of a Harsh English Tradition into a Modern Dilemma, 11 PEPPERDINE L. REV. 613, 614 (1984); see also S. REP. No. 225, supra note 4, at 191, reprinted in 1984 U.S. Code Cong. \& Admin. News at 3374 ("Today, few in the Congress or the law enforcement community fail to recognize that the traditional criminal sanctions of fine and imprisonment are inadequate to deter or punish the enormously profitable trade in dangerous drugs which, with its inevitable attendant violence, is plaguing the country.").

Recognition of the inadequacy of existing sanctions prompted acknowledgement of the need for more effective forfeiture penalties. "The drug trafficking laws produce unique problems at the post-conviction stage because the huge profits resulting from these enterprises tend to dampen the prospects for general deterrence or rehabilitation. ... Criminal forfeiture sanctions would seem to be the appropriate remedy." Hughes \& O'Connell, supra, at 613-14; see also S. REP. No. 225, supra note 4, at 191, reprinted in 1984 U.S. CODE CoNG. \& ADMIN. NEWs at 3374 ("Clearly, if law enforcement efforts to combat racketeering and drug trafficking are to be successful, they must include an attack on the economic aspects of these crimes. Forfeiture is the mechanism through which such an attack may be made.").

${ }_{72}$ See S. REP. No. 225, supra note 4, at 191, 193, reprinted in 1984 U.S. CoDE Cong. \& AdMIN. News at 3374, 3376. The provision was contained in title II, section 511 of the Comprehensive Drug Abuse Prevention and Control Act of 1970. The RICO statute contained the other forfeiture provision. See id.; infra notes 86-118 and accompanying text; see also Reed, Criminal Forfeiture Under the Comprehensive Forfeiture Act of 1984: Raising the Stakes, 22 AM. CRIM. L. REv. 747, 747 (1985) ("Un- 
Control Act of 1970 reduced penalties for most drug offenses in an attempt to encourage more prosecutions and thereby enhance the law's deterrent effect, it introduced severe penalties for those engaged in continuing criminal enterprises from which substantial profits were derived. ${ }^{73}$ The act was thus intended to "serve as a strong deterrent to those who otherwise might wish to engage in the illicit traffic."74 More specifically, "Congress recognized . . . that the conviction of individual racketeers and drug dealers would be of only limited effectiveness if the economic power bases of criminal organizations or enterprises were left intact, and so included forfeiture authority designed to strip these offenders and organizations of their economic power."75 The Supreme Court subsequently recognized that "Congress was plainly interested in punishing the professional criminal severely when it passed $\S 848$."78

The new forfeiture provision proved, however, relatively ineffective, in part because it contained "numerous limitations and ambiguities that . . . significantly impeded the full realization of forfeiture's potential as a powerful law enforcement weapon."77 Therefore, by passing the Comprehensive Crime Control Act of 1984, Congress "in-

til the enactment of the Racketeering Influenced and Corrupt Organizations Act (RICO) and the Continuing Criminal Enterprise statute (CCE) in 1970, forfeiture based on a criminal conviction was a concept foreign to the laws of the United States." (footnotes omitted)).

In fact, Congress had previously enacted a criminal forfeiture statute: the Confiscation Act of 1862, ch. 195, § 5, 12 Stat. 589, which "authorized the President to seize the property of those who had joined the Confederacy in the Civil War." Weiner, Crime Must Not Pay: RICO Criminal Forfeiture in Perspective, 1 N. ILL. L. REv. 225, 232 (1981). This act was effective, however, only against the life estates of the Confederate sympathizers; their heirs retained reversionary interests in the property. See id.

73 See H.R. REP. No. 1444, supra note 2, at 10-11, reprinted in 1970 U.S. CoDE Cong. \& ADMIN. News at 4575-76.

74 Id. at 10, reprinted in 1970 U.S. Code Cong. \& ADMIN. News at 4576. Nevertheless, some representatives worried that the "range of penalty" was still too wide, as it would "encompass offenses which range from hardly more than student peccadillos to hardened crime." Id. at 85, reprinted in 1970 U.S. CODE CONG. \& ADMin. News at 4652.

${ }^{76}$ S. REP. No. 225 , supra note 4 , at 191 , reprinted in 1984 U.S. CoDE CoNG. \& ADMIN. News at 3374.

${ }_{78}$ Jeffers v. United States, 432 U.S. 137, 156 n.26 (1976) (citing S. REP. No. 613, 91st Cong., 1st Sess. 2, 7 (1969); 116 Cong. Rec. 995, 1181, 1664 (1970) (remarks in Senate debate); $i d$. at 33,300-01, 33,304, 33,314 (remarks in House debate)).

77 S. REP. No. 225 , supra note 4 , at 191 , reprinted in 1984 U.S. Code CoNG. \& Admin. News at 3374 (citing General Accounting Office, Asset Forfeiture-A Seldom Used Tool in Combatting Drug Trafficking (1981)); see also id. at 194-97, reprinted in 1984 U.S. CoDE CONG. \& ADMIN. NEws at 3377-80 (noting, among other limitations of the then-existing forfeiture laws, the narrow scope of property subject to forfeiture; the failure to provide against a defendant's pretrial disposition of his assets; and the acute financial burdens of pursuing criminal forfeiture). 
tended to eliminate the statutory limitations and ambiguities that have frustrated active pursuit of forfeiture by Federal law enforcement agencies." The Act strongly encouraged the use of the criminal forfeiture provision by, for example, restricting pre-conviction transfer of property $^{79}$ and expanding the reach of the criminal forfeiture sanctions to cover all drug felonies within the scope of the Act. ${ }^{80}$ The legislative history demonstrates that the Act was intended to encourage criminal forfeiture proceedings instead of civil actions under section 881 in order to increase the efficiency of forfeiture actions. ${ }^{81}$

Thus, Congress was forcefully aiming both to increase the number of forfeitures and enhance their effectiveness. While Congressional debate over the scope of these statutes offered the McKeithen and Littlefield courts little specific guidance, what is nevertheless apparent is Congress's wish that criminal forfeiture be pursued to the fullest extent possible. ${ }^{82}$ This goal would be best achieved through the relatively severe forfeiture imposed in Littlefield.

Congress further indicated that courts interpreting section 853

78 Id. at 192, reprinted in 1984 U.S. Code Cong. \& Admin. News at 3375; see also 130 Cong. Rec. S13,078 (daily ed. Oct. 4, 1984) (statement of Sen. Kennedy) ("The overwhelming bipartisan support for this legislation marks the culmination of more than a decade of effort in Congress to deal . . . with the manifest flaws in our archaic criminal justice system."). United States v. Reynolds, 43 Crim. L. Rep. (BNA) 2463 (4th Cir. Sept. 14, 1988), interpreted this language to support a literal reading of section 881 that required forfeiture of a whole parcel of property when only a portion had been used to facilitate the offense. See id. at 2464 .

79 See S. REP. No. 225, supra note 4, at 211-12, reprinted in 1984 U.S. CoDE Cong. \& ADMIN. NEwS at 3394-95.

${ }^{80}$ See id. at 209-11, reprinted in 1984 U.S. Code Cong. \& Admin. News at 3392-94.

81 Congress hoped to clear up the backlog of civil forfeiture cases by creating an efficient process by which prosecutors could append the criminal forfeiture action onto the proceeding for the conviction for the substantive offense. See id. at 196-97, 210-11, reprinted in U.S. Code Cong. \& ADMIN. News at 3379-80, 3393-94; see also 130 CoNG. REC. S13,088 (daily ed. Oct. 4, 1984) (statement of Sen. D'Amato) ("We will . . e eliminate the most serious cause of the backlog in forfeiture cases, the requirement that a separate civil action be brought in each district where property is found.").

Congress was trying to develop a comprehensive program to deal with the drug problem. "[F]orfeiture of drug trafficker's assets will be a crucial element of the Federal antidrug strategy. The strategy will define how the various agencies will contribute to improving the number and level of forfeiture cases." Id. at S13,065 (statement of Sen. Biden); see also S. ReP. No. 225, supra note 4, at 209-10, reprinted in 1984 U.S. CODE CoNG. \& ADMIN. News at 3392-93 (comparing the advantages and disadvantages of civil forfeiture proceedings to those of criminal forfeiture proceedings).

82 See, e.g., 130 Cong. REc. S13,088 (daily ed. Oct. 4, 1984) (statement of Sen. D'Amato) ("We are telling the courts to take the broadest possible view of what propertly [sic] is subject to confiscation as proceeds of drug trafficking. . . . The goal of our legislation . . . is nothing less than stripping the drug kingpins of their drug-profit empires."). 
could look both to the RICO forfeiture statute ${ }^{83}$ and the civil forfeiture provisions of Title $21^{84}$ for guidance. Those provisions indicate that property involved in drug offenses should be forfeited in its entirety. ${ }^{85}$

\section{Section 1963: The RIGO Forferture Provision}

The Racketeering Influenced and Corrupt Organization statute contains a forfeiture provision, 18 U.S.C. $\S 1963,{ }^{86}$ that is analogous to

ss See S. REP. No. 225, supra note 4, at 209, reprinted in 1984 U.S. ConE Cong. \& ADMIN. News at 3392 ("This statute is, in nearly all respects, identical to the RICO criminal forfeiture statute as amended . ...."); id. at 210, reprinted in 1984 U.S. Code Cong. \& ADMIN. News at 3393 ("To the greatest extent possible, the provisions of the title 21 criminal forfeiture statute . . p parallel those of amended RICO criminal forfeiture provisions . . . ."); see also United States v. Amend, 791 F.2d 1120, 1127 n.6 (4th Cir.) ("The RICO and CCE forfeiture provisions are similar."), cert. denied, 474 U.S. 930 (1986); United States v. Premises Known as 3301 Burgundy Rd., Alexandria, Va., 728 F.2d 655, 657 n.3 (4th Cir. 1984) ("[T]he court could have relied on either 21 U.S.C. $\$ 848$, or 18 U.S.C. $\$ 1963$. . . It matters little, however, which of these two forfeiture provisions the court meant to cite. The provisions have similar requirements."); $c f$. Russello v. United States, 464 U.S. 16, 25 (1983) ("Members of Congress who voted for the RICO statute were aware of the Controlled Substances Act. It is most unlikely, however, that without explanation a potent forfeiture weapon was withheld from the RICO statute, intended for use in a broad assault on organized crime, while the same weapon was included in the Controlled Substances Act." (citations omitted)).

84 The Senate Judiciary Committee stated:

The type of property which is subject to criminal forfeiture under paragraph (2) is that which is "used, or intended to be used . . . to commit, or to facilitate the commission of" the offense for which the defendant was convicted. This is generally the manner in which property subject to civil forfeiture is defined in 21 U.S.C. 881, although section 881 refers to specific types of property. . . . Subsection (a)(2) of the bill's criminal forfeiture statute, on the other hand, refers simply to "property" used in the violation.

S. REP. No. 225, supra note 4, at 211, reprinted in 1984 U.S. CoDE CoNG. \& ADMIN. News at 3394.

ss See infra notes 86-118 and accompanying text (supporting a broad interpretation of the RICO forfeiture provision); infra notes 119-56 and accompanying text (supporting a broad interpretation of the civil forfeiture provision of Title 21).

88 18 U.S.C. § 1963(a) (Supp. IV 1986) provides in relevant part:

(a) Whoever violates any provision of section 1962 of this chapter . . . shall forfeit to the United States, irrespective of any provision of State law-

(1) any interest the person has acquired or maintained

in violation of section 1962;

(2) any-

(A) interest in;

(B) security of;

(C) claim against; or

(D) property or contractual right of any kind affording a source of influence over;

any enterprise which the person has established, operated, controlled, conducted, or participated in the conduct of, in violation of section $1962 \ldots .$. 
section $853{ }^{87}$ This similarity was expressly intended by Congress. ${ }^{88}$ Because the RICO forfeiture provision has been the subject of more litigation than both sections 848 and 853 , it provides valuable guidance on the question of real property forfeiture.

The RICO case most directly on point is United States $v$. Anderson ("Anderson $I I$ ") ${ }^{89}$ In Anderson II, the defendant's interest in a nightclub was subjected to forfeiture pursuant to section 1963. The defendant argued that the basement of his nightclub, which was rented out to other businesses as a storage area, should be exempt from such forfeiture. ${ }^{90}$ The Eleventh Circuit rejected this argument, stating that "[a] defendant's conviction under the RICO statute subjects all his interests in the enterprise to forfeiture 'regardless of whether those assets were themselves "tainted" by use in connection with the racketeering activity." "g1

The case upon which Anderson $I I$ relied for its view of the relevance of "taint," United States v. Cauble, ${ }^{92}$ stated that "[t]he RICO forfeiture is in personam: a punishment imposed on a guilty defendant. It deprives that defendant of all of the assets that allow him to maintain an interest in a RICO enterprise, regardless whether those assets are themselves 'tainted' by use in connection with the racketeering activity." "93 The only issues, therefore, presented by mandatory section 1963

87 For the text of $\$ 853$, see supra note 22 .
88 See supra note 83 .
88 782 F.2d 908 (11th Cir. 1986). This case is unrelated to Anderson $I$.
80 See id. at 917 .
91 Id. at 918 (quoting United States v. Cauble, 706 F.2d 1322, 1349 (5th Cir. 1983)) (emphasis added by Anderson II court). McKeithen distinguished Anderson II, arguing that it "relate[d] to forfeiture of a defendant's interest in a criminal enterprise itself and not to forfeiture of his other property." United States v. McKeithen, 822 F.2d 310, 314 (2d Cir. 1987). This distinction between the two cases seems to rest on the $M c K e i t h e n$ court's perception that the basement was part of the Anderson II defendant's nightclub/criminal enterprise, while, in McKeithen, the apartment rented to tenants was not part of his enterprise and did not afford him a source of influence over the building from which drugs were sold, even though both were on the same piece of property. See id. at 312,314 . The McKeithen court accepted the Anderson II court's assumption that the basement was a necessary and indistinguishable part of the nightclub enterprise, but dismissed the apartment building as "other property" of McKeithen that should not be subject to forfeiture. Id. at 314. The court did not elaborate on its distinction; perhaps it was influenced by the fact that Anderson $I I$ involved one building compared to the two in McKeithen. It also might have seen the business in Anderson $I I$ as the owner of the basement. Although this distinction is plausible, it could allow drug traffickers to use, for example, separate corporations to protect property that is not actively used in the criminal activity. It would seem perverse to allow the limited liability of the corporate form to reduce criminal liability for drug traffickers.

${ }_{92} 706$ F.2d 1322 (5th Cir. 1983), cert. denied, 465 U.S. 1005 (1984).

9s Id. at 1349. The defendant had argued that the jurors should have been fur- 
forfeiture are "whether the defendant violated RICO and what interest the defendant held in the enterprise."

The Second Gircuit reached a similar conclusion in United States v. Walsh, ${ }^{95}$ arguing that

[t]he RICO forfeiture provision was designed to impose forfeiture upon a defendant's entire interest in the RICO enterprise . . . so as to sever his connection with it. Determining the degree of the enterprise's criminal taint is not contemplated by the statute. ... Differentiating between those parts of a RICO enterprise engaged in racketeering activity and those that are not is not a requirement under the statute for determining whether a defendant's interest is subject to forfeiture. . . . [F]or purposes of the statute, the assets of a RICO enterprise are indivisible. ${ }^{98}$

The legislative history cited in Walsh ${ }^{97}$ states that section 1963(a) provides that "violations shall be punished by forfeiture to the United States of all property and interests, as broadly described, which are related to the violations." ${ }^{\text {"98 }}$ Although this sentence gives mixed signals as to whether the assets must be "tainted" by illegal activity, the Cauble and Walsh interpretation seems the most convincing in light of the 1984 amendments to the RICO forfeiture provisions. ${ }^{\text {99 }}$

nished a list of the enterprise's assets "so that they might forfeit only those that were the basis for [the defendant's] control," and complained that the jury was not "asked to determine what 'manner of forfeiture' would deprive him of his influence over the enterprise." Id.

Id. (citing United States v. Hess, 691 F.2d 188, 190-91 (4th Cir. 1982)).

os 700 F.2d 846 (2d Cir.), cert. denied, 464 U.S. 825 (1983). In Walsh, the defendant argued that the "forfeiture verdict was not supported by sufficient evidence since no proof was presented to the jury as to what extent [the defendant's firm's] assets were tainted by criminal conduct." Id. at 857 .

Id. (citing United States v. Huber, 603 F.2d 387, 394 (2d Cir. 1979), cert. denied, 445 U.S. 927 (1980); United States v. Rubin, 559 F.2d 975, 991-92 (5th Cir. 1977), vacated and remanded, 439 U.S. 810 (1978); H.R. REP. No. 1549, 91st Cong., 2d Sess. 56-57, reprinted in 1970 U.S. Code Cong. \& ADmIN. News 4007, 4033). The Second Circuit in McKeithen distinguished Walsh because it construed the phrase "interest in" an enterprise, rather than "property . . . affording a source of influence over[] any enterprise." See United States v. McKeithen, 822 F.2d 310, 314 (2d. Cir. 1987). Because, however, the congressional purpose behind forfeiture remains the same for either phrase, such differences in statutory language should not affect the underlying philosophy of criminal forfeiture.

${ }_{97}$ See H.R. REP. No. 1549, supra note 96, at 57, reprinted in 1970 U.S. CodE Cong. \& ADMIN. News at 4033, cited in Walsh, 700 F.2d at 857.

${ }_{98}$ H.R. REP. No. 1549, supra note 96, at 57, reprinted in 1970 U.S. CodE Cong. \& ADMIN. News at 4033.

92 Congress used the word "taint" only in the context of forfeiture relating back to the time of the illegal acts, which thus gives the United States an interest in the property prior to any transfer of the property after the violation. See S. Rep. No. 225, 
Forfeiture under section 1963(a)(2) covers "any . . . interest in; ... or ... property or contractual right of any kind affording a source of influence over; any enterprise which the person has established, operated, controlled, conducted, or participated in the conduct of, in violation of section 1962." ${ }^{\prime 100}$ Section 1963(a)(3), added in 1984 to make clear the intent of Congress to include proceeds of RICO enterprises in section 1963 forfeitures, is limited to "any proceeds which the person obtained, directly or indirectly, from racketeering activity."101 Thus, forfeiture of interests in, or property affording an influence over, the enterprise is keyed to the enterprise itself, while forfeiture of proceeds is limited to those stemming from the illegal activity. The Supreme Court noted this distinction in Russello $v$. United States, ${ }^{102}$ in which it interpreted section 1963 to include forfeiture of such proceeds before section 1963(a)(3) was added to the statute. The court argued that:

Had Congress intended to restrict $\S 1963$ (a)(1) to an interest in an enterprise, it presumably would have done so expressly as it did in the immediately following subsection (a)(2). . . . We refrain from concluding here that the differing language in the two subsections has the same meaning in each. We would not presume to ascribe this difference to a simple mistake in draftsmanship. ${ }^{103}$

Likewise, forfeiture keyed to the racketeering enterprise in section 1963(a)(2) should not be construed as limited to the racketeering activity specified in section 1963(a)(3).

When applied to section 853 , this principle supporting broad forfeitures would require that persons convicted under the statute forfeit entire parcels of real property involved in the continuing criminal enterprises to which section $853(\mathrm{a})(3)$ is keyed, ${ }^{\mathbf{1 0 4}}$ rather than merely those portions of the property "tainted" by the illegal activity. Both RICO and the Comprehensive Drug Abuse Prevention and Control

supra note 4, at 195-96, 200-01, reprinted in 1984 U.S. Code Cong. \& ADMIN. NEws at $3378-79,3383-84$.

10018 U.S.C. \& 1963(a)(2) (Supp. IV 1986) (emphasis added).

${ }_{101} I d$. $\S 1963$ (a)(3) (emphasis added); see also S. REP. No. 225, supra note 4, at 199, reprinted in 1984 U.S. CoDE Cong. \& ADMIN. NEws at 3382 ("[P]roceeds accruing to an enterprise or association involved in a RICO violation will be forfeitable only to the extent that they are derived from racketeering activity ....").

102464 U.S. 16 (1983).

${ }^{103} I d$. at 23 (citations omitted).

104 For a discussion of facilitation of drug felonies, which can bring about forfeiture pursuant to section 853(a)(2) or section 881, see infra notes 136-56 and accompanying text. 
Act incorporated the principle that "conviction of individual racketeers and drug dealers would be of only limited effectiveness if the economic power bases of criminal organizations or enterprises were left intact, and so included forfeiture authority designed to strip these offenders and organizations of their economic power."108 This purpose mandates that specific "taint" not be a prerequisite for forfeiture, because it would eviscerate the forfeiture provisions. Instead, entire parcels, rather than parts, of real property should be forfeited.

The development of RICO case law also is of assistance in interpreting the forfeiture provisions. When the RICO forfeiture provision did not specifically require forfeiture of the proceeds of criminal enterprises, numerous courts interpreted the provision as applying only to interests in the enterprise itself, leaving untouched any proceeds of the enterprise. ${ }^{106}$ The Supreme Court overruled all these cases in Russello when it held that the word "interest" in section 1963(a)(1), which required forfeiture of " any interest . . . acquired or maintained in violation of section 1962," "107 covered insurance proceeds from an arson scheme. ${ }^{108}$ The Court based its argument on its recognition that Gongress had chosen the word "interest" for its breadth, ${ }^{109}$ and that the word thus covered "an 'interest' in the ill-gotten gains." 110 The Court also emphasized that the legislative history clearly shows "that the RICO statute was intended to provide new weapons of unprecedented scope for an assault upon organized crime and its economic roots,"111 and that "the intent to authorize forfeiture of racketeering profits seems obvious,"112 given that "the broader goal was to remove the profit from organized crime by separating the racketeer from his dishonest

103 S. REP. No. 225, supra note 4, at 191, reprinted in 1984 U.S. Code Cong. \& ADMIN. NEWS at 3374.

108 See, e.g., United States v. McManigal, 708 F.2d 276, 283-87 (7th Cir.), vacated, 464 U.S. 979 (1983) (arguing that § 1963 should be narrowly construed to exclude proceeds, because if Congress had wanted to include proceeds, it would have done so expressly, as it did in the Comprehensive Drug Abuse Prevention and Control Act of 1970); United States v. Marubeni Am. Corp., 611 F.2d 763, 766-69 (9th Cir. 1980) (specifying that "interest" as it is used in $\S 1963(\mathrm{a})(1)$ does not mean income or proceeds derived from a pattern of racketeering activity); United States v. Thevis, 474 F. Supp. 134, 141-42 (N.D. Ga. 1979) (noting the distinction between "an interest" and "income"); United States v. Meyers, 432 F. Supp. 456, 461 (W.D. Pa. 1977) (concluding "that an interest is akin to a continuing proprietary right in the nature of partnership or stock ownership. . . rather than mere dividends or distributed profits").

${ }^{107}$ Russello, 464 U.S. at 20 (quoting 18 U.S.C. $§ 1963($ a)(1) (1982)).

${ }^{108}$ See id. at 22.

109 See id. at 21.

$110 I d$. at 22.

111 Id. at 28.

${ }^{112}$ Id. 
gains."11s Finally, the Court recited as additional support Congress's instruction that " [ $[\mathrm{t}] \mathrm{he}$ provisions of this title shall be liberally construed to effectuate its remedial purposes.' "114

The Russello Court's broad interpretation of RICO fits section 853 perfectly. The section 853 requirement that "any . . . property" and "any . . . interest" be forfeited indicates a breadth similar to that found by the Supreme Court in the RICO forfeiture provision. Section 853 also contains a provision mandating liberal construction of the statute. ${ }^{115}$ Finally, Congress regarded the two forfeiture provisions as essentially identical, ${ }^{116}$ the language of each provision tracks the other, ${ }^{117}$ and the legislative history of section 853 indicates that Congress intended for section 853 to have the same impact on drug offenders as Congress envisaged RICO would have on organized crime. ${ }^{118}$ Thus, section 853 , like RICO, should be construed as broadly as possible to inflict maximum economic damage on drug offenders. Achievement of this end would be facilitated by requiring the complete forfeiture of real property involved in drug felonies.

$118 I d$.

114 Id. at 27 (quoting Organized Crime Control Act of 1970, Pub. L. No. 91-452, § 904(a), 84 Stat. 922, 947). Compare id. with 21 U.S.C. § 853(o) (Supp. IV 1986) ("The provisions of this section shall be liberally construed to effectuate its remedial purposes.").

${ }_{115}$ See 21 U.S.C. $\S 853($ ) (Supp. IV 1986).

116 See supra note 83; of. Russello, 464 U.S. at 25 (noting that, although statutes enacted at the same time do not necessarily shed light on each other, in this case it was unlikely that Congress withheld "without explanation a potent forfeiture weapon ... from the RICO statute, intended for use in a broad assault on organized crime, while the same weapon was included in the Controlled Substances Act [section 848(a)(2)], meant for use in only one part of the same struggle").

${ }_{117}$ Compare 18 U.S.C. \& 1963(a) (Supp. IV 1986) ("Whoever violates any provision of section 1962 of this chapter . . . shall forfeit to the United States, irrespective of any provision of State law - (1) any interest the person has acquired or maintained in violation of section 1962; (2) any - (A) interest in; (B) security of; (C) claim against; or (D) property or contractual right of any kind affording a source of influence over; any enterprise which the person has established, operated, controlled, conducted, or participated in the conduct of, in violation of section 1962 ....") with 21 U.S.C. $\S 853$ (a) (Supp. IV 1986) ("Any person convicted of a violation of this subchapter or subchapter II of this chapter punishable by imprisonment for more than one year shall forfeit to the United States, irrespective of any provision of State law- . . (2) any of the person's property used, or intended to be used, in any manner or part, to commit, or to facilitate the commission of, such violation; and (3) in the case of a person convicted of engaging in a continuing criminal enterprise in violation of section 848 of this title, the person shall forfeit, in addition to any property described in paragraph (1) or (2), any of his interest in, claims against, and property or contractual rights affording a source of control over, the continuing criminal enterprise.").

${ }^{118}$ See supra note 83 and accompanying text. 


\section{Section 881: The Givil Forfeiture Provision}

Section 881 of the Comprehensive Drug Abuse Prevention and Control Act provides for civil forfeitures. The various provisions of section 881 are worded much like section $853(\mathrm{a})(2)$, the provision at issue in United States $v$. Littlefield, ${ }^{119}$ except that each section deals specifically with a different type of property. Section 881(a)(7) deals specifically with forfeiture of real property. ${ }^{120}$ Congress has clearly stated its belief that section 853 covers property in "generally the manner in which property subject to civil forfeiture is defined in 21 U.S.C. 881 , although section 881 refers to specific types of property."121 The Ninth Circuit reasoned convincingly that the criminal forfeiture provision should be interpreted no less broadly than section $881 .{ }^{\mathbf{1 2 2}}$

The Littlefield court pointed out that Congress intended that section 853 forfeiture proceedings accomplish precisely the same ends as section 881 , only more efficiently, because the forfeiture issue would be tried in the same proceeding as the criminal action. ${ }^{123}$ Thus, despite

118821 F.2d 1365 (9th Cir. 1987).

12021 U.S.C. § 881(a)(7) (Supp. IV 1986) provides:

(a) The following shall be subject to forfeiture to the United States and no property right shall exist in them:

(7) All real property, including any right, title, and interest in the whole of any lot or tract of land and any appurtenances or improvements, which is used, or intended to be used, in any manner or part, to commit, or to facilitate the commission of, a violation of this subchapter punishable by more than one year's imprisonment, except that no property shall be forfeited under this paragraph, to the extent of an interest of an owner, by reason of any act or omission established by that owner to have been committed or omitted without the knowledge or consent of that owner.

Even before the enactment of section $881(\mathrm{a})(7)$, however, at least two courts had found that section $881(a)(6)$ covered real property as proceeds of an illegal exchange of controlled substances. See United States v. Premises Known as 8584 Old Brownsville Rd., 736 F.2d 1129, 1131 (6th Cir. 1984); United States v. Certain Real Property Situated At Route 3, 568 F. Supp. 434, 436 (W.D. Ark. 1983).

121 S. REP. No. 225, supra note 4, at 211 , reprinted in 1984 U.S. CODE CoNG.

\& ADMIN. NEws at 3394.

122 See supra notes 60-62 and accompanying text.

${ }^{123}$ The Littlefield court quoted a Senate report on this issue:

"Where the issues relating to civil forfeiture are the same as or closely related to those that will arise in the prosecution of a drug offense, it is a waste of valuable judicial and prosecutive resources to require separate civil forfeiture proceedings .....

Thus, a more efficient mechanism for achieving the forfeiture of a defendant's proceeds from his drug trafficking or of other property he has used in the offense is to permit the criminal forfeiture of such property and thereby consolidate the forfeiture action with the criminal prosecution. [21 U.S.C. $§ 853$ ] creates such a mechanism."

Littlefield, 821 F.2d at 1367-68 (quoting S. REP. No. 225, supra note 4, at 210 , reprinted in 1984 U.S. Code Cong. \& ADMIN. News at 3393). 
their procedural differences, sections 881 and 853 should rely on the same analysis of the scope of real property forfeiture: "It would frustrate the goals of judicial and prosecutorial efficiency to construe section 853 as covering only a portion of property that section 881 reaches in its entirety."124

The extent to which real property should be forfeited has been discussed in the context of the civil forfeiture provision. In United States v. Two Tracts of Real Property in Bruce Township, North Carolina, ${ }^{125}$ the district court posed a question not addressed by either party: "whether the entirety of tract two was forfeit, even though the evidence showed only that the house, pool, and driveway had any connection with the illegal drug transactions." ${ }^{226}$ The court looked at the statutory history of the provision" ${ }^{127}$ and concluded that "Congress has clearly mandated the widespread use of various forfeiture proceedings as weapons in the war on drugs." 128 In sum, the court was "of the opinion that the plain language of the statute, coupled with the obvious intent of Congress to strengthen and make more effective civil forfeiture provisions, mandates a conclusion that the entirety of each tract of land wherein the Government maintains its burden of proof must be forfeit." 128

A recent civil case was even more blunt. United States $v$. Reynolds $s^{130}$ also involved a tract of property-over thirty acres of land on

\footnotetext{
124 Id. at 1368.

${ }^{125} 665$ F. Supp. 422 (M.D.N.C. 1987).

${ }^{128} I d$. at $425-26$.
}

${ }^{127}$ The court quoted a Senate report: "This bill is intended to eliminate the statutory limitations and ambiguities that have frustrated active pursuit of forfeiture by Federal law enforcement agencies." "Id. at 426 (quoting S. REP. No. 225, supra note 4 , at 192, reprinted in 1984 U.S. CoDE Cong. \& ADMIN. NEws at 3375). This language also applies to the amended criminal forfeiture statute. See supra note 79 and accompanying text.

${ }^{128}$ Two Tracts of Real Property, 665 F. Supp. at 426 (citing Russello v. United States, 464 U.S. 16, 28 (1983) (broadly construing 18 U.S.C. $§ 1963$, the criminal forfeiture provision of the RICO statute)).

${ }^{128}$ Id. (citing Littlefield, 821 F.2d at 1365). The court did, however, state that "forfeiture is a drastic procedure, and the court is of the opinion that the Government must carry its burden of proof with respect to each tract of land individually and not as a collective whole." Id. The court's statement points out the problem of how to determine the extent of a tract or parcel of real property. The court in United States v. McKeithen, 822 F.2d 310 (2d Cir. 1987), stated that it did not "think it appropriate that a question of criminal forfeiture under federal law should turn upon the nuances and niceties of local real property laws." Id. at 313. It would also frustrate the aims of the forfeiture provisions, see supra notes 67-85 and accompanying text, to allow drug traffickers to avoid forfeitures by subdividing their property into distinct lots. A more in-depth analysis of this issue, however, is beyond the scope of this Comment.

13043 Grim. L. Rep. (BNA) 2463 (4th Gir. Sept. 14, 1988). 
which only the house, driveway, and swimming pool had been used to facilitate the distribution of cocaine. ${ }^{131}$ The court stated that "[t]he words of the statute alone" indicated that "Congress expressly contemplated forfeiture of an entire tract based upon drug-related activities on a portion of the tract. The statute is so clear that resort to extrinsic aids to seek its meaning are unnecessary."132 Nevertheless, the court noted that the legislative history of the statute also supported a literal construction. ${ }^{133}$

This interpretation is in keeping with the rather harsh forfeiture orders often handed down under section 881. For example, in one case, the defendant was ordered to forfeit her Porsche $911 \mathrm{~S}$ after .226 grams of marijuana were found in a plastic bag in the trunk. ${ }^{134}$ In another, the defendant had to forfeit a twenty-eight-foot boat after two leaves and a twig of marijuana were found stuck in the crevice of a board in a compartment underneath a gas tank. ${ }^{135}$

The extent of forfeiture in section 881 cases often hinges on the court's interpretation of the word "facilitate." Some circuits have held that property has facilitated a crime, and is therefore subject to forfeiture, ${ }^{137}$ if it has been used "in any manner" in connection with an

131 See id. at 2463 (Digest of Opinion). This wave of swimming pool use in drug offenses demonstrates how criminals may use property to facilitate crime in not so obvious ways. For example, if used for entertaining others engaged in drug trafficking, the pools could serve as a springboard from which to launch an expansion of business just as easily as would a three-martini lunch or a weekend golf junket.

${ }^{132} I d$. at 2464.

13s See id.

134 See United States v. One 1976 Porsche 911S, 670 F.2d 810, 812 (9th Cir. 1979). The court concluded that "it was likely the matter constituted the remains of a larger quantity of marijuana, especially in light of its location in the vehicle." Id.

${ }^{135}$ See United States v. One (1) 1982 28' Int'l Vessel, 741 F.2d 1319, 1320 (11th Cir. 1984). In addition, "[t]he bilge water also tested positive for marijuana." Id. This case, even more obviously than One 1976 Porsche $911 S$, involved a vehicle carrying large quantities of marijuana. This further justifies the harsh penalties imposed on drug traffickers even when at first glance the violation seems minor.

138 "Facilitation" has been given a broader interpretation in section 881 than in some other civil forfeiture statutes because Congress modified it with the phrase "in any manner." See ASSET Forfeiture Office, U.S. Dep'T OF Justice CRIMINAL Div., Forfeitures Volume I: INTroduction to Givil STATUTES 13-18 (1984); $c f$. United States v. One 1974 Cadillac Eldorado Sedan, 548 F.2d 421, 425 (2d Cir. 1977) (concluding that the words "in any manner to facilitate," as in 21 U.S.C. $\S 881$ (a)(4), have broader meaning than just "to facilitate," as in 49 U.S.C. $\S 782$ ). This consideration applies equally to section 853. See infra notes $146-47$ and accompanying text.

${ }_{137}$ These cases have arisen primarily under 21 U.S.C. $§ 881$ (a)(4) (1982), which states in relevant part:

(a) The following shall be subject to forfeiture to the United States and no property right shall exist in them:

(4) All conveyances, including aircraft, vehicles, or vessels, which are used, or are intended for use, to transport, or in any manner to facilitate the 
illegal drug transaction ${ }^{\mathbf{1 3 8}}$ or if it has in any way tended to make drug trafficking easier. ${ }^{139}$

The Second Circuit examined the language and intent of section 881(a)(4) and concluded that the phrase "in any manner to facilitate" " and "the congressional intent to broaden the applicability of the forfeiture remedy" supported a broad interpretation of the statute. ${ }^{\mathbf{1 4 0}}$ Consequently, an automobile was subject to forfeiture when used to convey the parties to a meeting to discuss a subsequent drug deal. ${ }^{\mathbf{1 4 1}}$ The court also indicated a willingness to look expansively at drug-related forfeitures when it remarked that

[a]s a matter of common sense we cannot accept the concept that while the transportation of any quantity of drugs however minute is admittedly sufficient to merit the forfeiture of the vehicle, nonetheless the transportation of the trafficker to the site of the drug sale or to a prearranged meeting with a prospective customer where the sale is proposed should save the vehicle from forfeiture. ${ }^{142}$

Similarly, the Fifth Circuit found that "[a] $\S 881$ forfeiture is proper if the vehicle in question was used 'in any manner' to facilitate the sale or transportation of a controlled substance or raw material used in the manufacture of a controlled substance."143

The Third Circuit took an even broader view of the meaning of "facilitate," stating the test as "whether there was a reasonable ground for belief that the use of the automobile made the sale less difficult and allowed it to remain more or less free from obstruction or

transportation, sale, receipt, possession, or concealment of property described in paragraph (1) or (2) ....

${ }^{138}$ See United States v. 1964 Beechcraft Baron Aircraft, 691 F.2d 725, 727 (5th Cir. 1982), cert. denied, 461 U.S. 914 (1983); One 1974 Cadillac Eldorado Sedan, 548 F.2d at 423.

139 See United States v. One 1977 Lincoln Mark V. [sic] Coupe, 643 F.2d 154, 157 (3d Cir.), cert. denied, 454 U.S. 818 (1981).

140 One 1974 Cadillac Eldorado Sedan, 548 F.2d at 425.

141 See id. at 427.

142 Id. at 425.

${ }_{143}$ United States v, 1964 Beechcraft Baron Aircraft, 691 F.2d 725, 727 (5th Cir. 1982) (citing United States v. One 1979 Mercury Cougar XR-7, 666 F.2d 228, 230 (5th Cir. 1982)), cert. denied, 461 U.S. 914 (1983). The court also pointed out that, while the legislative history for section $881(\mathrm{a})(6)$, a subsequently added provision requiring forfeiture of money and things of value negotiated in exchange for drugs, required a "substantial connection," "that amendment's legislative history makes no mention of using the same test for other forfeiture actions and the legislative history of $\S 881$ is devoid of any mention of a 'substantial connection' test." Id. 
hinderance [sic]." "'144 The court stated that

even if the packets placed in the trunk of the car did not contain heroin, there was sufficient evidence to support a finding of probable cause that the car was used to "facilitate" the sale of a controlled substance. . . . The presence of the automobile with its hood up provided a convenient cover whereas two men alone in an alley might have appeared suspicious. ${ }^{145}$

This expansive reading of the statute illustrates how courts may look for the more subtle and indirect ways in which property can facilitate a narcotics offense. Given the language of the statutes and the determination of Congress to punish drug traffickers harshly, there is no reason for courts to go out of their way to restrict the scope of forfeiture.

The broad interpretation given by these circuits to the phrase "in any manner to facilitate" is equally applicable to criminal forfeiture under section 853(a)(2). ${ }^{148}$ Applied to real property, this interpretation of section 881 would favor forfeiture of whole parcels of property for many of the reasons discussed in Part I. ${ }^{147}$

Other circuits have, however, held that property must be "substantially connected" to the criminal activity before it will be subject to forfeiture. ${ }^{148}$ Two of these cases concerned real property, ${ }^{149}$ and the courts' application of the "substantially connected" standard resembled the Second Circuit's interpretation of section 848 in McKeithen. Both analyses, however, actually seem to favor the opposite interpretation.

Both district courts pointed out that Congress added section $881(\mathrm{a})(7)$ to the civil forfeiture statute in order to close a loophole that

144 See One 1977 Lincoln Mark V. [sic] Coupe, 643 F.2d at 157 (misquoting United States v. One 1950 Buick Sedan, 231 F.2d 219, 222 (3d Cir. 1956) (quoting Funk and Wagnalls)).

168 Id.

160 Section 853(a)(2) subjects to forfeiture "any of the person's property used, or intended to be used, in any manner or part, to commit, or to facilitate the commission of, such violation."

167 See supra notes $35-48$ and accompanying text.

146 Compare, e.g., United States v. 1966 Beechcraft Aircraft Model King Air, 777 F.2d 947, 953 (4th Cir. 1985) (ruling that the use of an aircraft to transport either drugs or participants to the scene of a drug transaction established a "substantial connection" to the illegal activity) with, e.g., United States v. One 1976 Ford F-150 PickUp, 769 F.2d 525, 527 (8th Cir. 1985) (ruling that the use of a truck on one occasion to inspect a marijuana crop was not sufficient to subject it to forfeiture).

160 See United States v. Twelve Thousand Five Hundred Eighty-Five Dollars, 669 F. Supp. 939, 942-43 (D. Minn. 1987) (holding that one drug sale at a house was not a "substantial" enough connection to warrant forfeiture of the property); United States v. Certain Lots in Va. Beach, Va., 657 F. Supp. 1062, 1064-65 (E.D. Va. 1987) (same). 
had prevented the government from reaching real property in civil forfeiture proceedings. ${ }^{150}$ Both quote the same passage from the Senate report on the amendment:

Under current law, if a person uses a boat or car to transport narcotics or uses equipment to manufacture dangerous drugs, his use of the property renders it subject to civil forfeiture. But if he uses a secluded barn to store tons of marihuana or uses his house as a manufacturing laboratory for amphetamines, there is no provision to subject his real property to civil forfeiture, even though its use was indispensible to the commission of a major drug offense and the prospect of the forfeiture of the property would have been a powerful deterrent. $^{151}$

The courts explain that "[t]he example and language used in the Senate report illustrate Congress's intent to subject real property to forfeiture only if the property is substantially connected to illegal drug activity,"152 and that "[w]hile $\S 881(a)(7)$ does not require that forfeited property be 'indispensable to the commission of a major drug offense,' Congress evidently did not intend the forfeiture statute to apply to property which has only an incidental or fortuitous connection to criminal activity."153

This interpretation is implausible. The quoted passage more likely reflects Congress's exasperation over the ability of drug dealers to escape forfeiture of real property even in the egregious examples cited. There is no indication that Congress intended to limit forfeiture to such instances; instead, the passage seems aimed at highlighting the problem by use of vivid examples.

This view is supported by the context of the passage in the legislative history. The Senate Judiciary Committee expressed its frustration that section 881 could not reach real property immediately after having expressed a similar frustration with cases holding that RICO did not reach the proceeds of racketeering activity. ${ }^{154}$ The passage quoted by both courts is prefaced by the remark that "[ $t]$ he extent of drug-related

150 See Twelve Thousand Dollars, 669 F. Supp. at 943; Virginia Beach, 657 F. Supp. at 1064.

${ }^{161}$ Twelve Thousand Dollars, 669 F. Supp. at 943 (misquoting S. REP. No. 225, supra note 4, at 195, reprinted in 1984 U.S. CoDE CoNG. \& ADMIN. News at 3378) (additional emphasis of court deleted, no emphasis in Senate Report); Virginia Beach, 657 F. Supp. at 1065 (quoting same) (emphasis added by court).

${ }_{182}$ Twelve Thousand Dollars, $669 \mathrm{~F}$. Supp. at 943.

15 Virginia Beach, 657 F. Supp. at 1065.

184 See S. Rep. No. 225, supra note 4, at 194-95, reprinted in 1984 U.S. CodE Cong. \& ADmin. News at 3377-78. 
property subject to civil forfeiture under 21 U.S.C. 881 is also too limited in one respect." 165 This one deficiency was that section 881 failed to reach real property, not that it failed to reach only real property directly implicated in especially egregious drug offenses. If Congress had intended to limit forfeiture, it could have said so much more clearly; instead, the Comprehensive Forfeiture Act was explicitly "designed to enhance the use of forfeiture," a weapon in the fight against one "of the most serious crime problems facing the country: ... drug trafficking."158 Given this context, the narrow approach of the district courts is inappropriate.

\section{Eighth Amendment Gonsiderations}

A number of courts have noted that RICO's forfeiture provision could violate the eighth amendment ${ }^{167}$ in extreme cases. ${ }^{158}$ Thus, although the Ninth Gircuit in United States v. Littlefield ${ }^{15 \theta}$ required, under section 853(a)(2), forfeiture of an entire parcel of property for a drug crime committed on a portion of that property, ${ }^{160}$ it remanded the case to the district court for review of eighth amendment considerations in light of its decision in United States $v$. Busher. ${ }^{161}$ The Littlefield court stated that "criminal forfeiture is a form of punishment and therefore subject to the eighth amendment's prohibition against disproportionate punishment."162 Thus, the mandatory forfeiture exacted must not be "so disproportionate to the offense committed as to violate

${ }^{165}$ Id. at 195, reprinted in 1984 U.S. CODE CONG. \& ADMIN. NewS at 3378.

${ }^{156}$ Id. at 191, reprinted in 1984 U.S. CoDE CONG. \& ADMIN. News at 3374.

${ }_{157}$ The eighth amendment reads: "Excessive bail shall not be required, nor excessive fines imposed, nor cruel and unusual punishments inflicted." U.S. CoNST. amend. VIII.

${ }^{188}$ See, e.g., United States v. Horak, 833 F.2d 1235, 1251 (7th Cir. 1987) ("We are not insensitive to the concern that vast prosecutorial discretion in combination with potentially enormous forfeiture orders might in some circumstances threaten Eighth Amendment rights."); United States v. Walsh, 700 F.2d 846, 857 (2d Gir.) ("The only apparent limitations upon this complete forfeiture [include] the Eighth Amendment's prohibition against cruel and unusual punishment . . . ."), cert. denied, 464 U.S. 825 (1983); United States v. Marubeni Am. Corp., 611 F.2d 763, 769 n.12 (9th Cir. 1980) ("The forfeiture provision could, indeed, be read to produce penalties shockingly disproportionate to the offense. For example, a shopkeeper who over many years and with much honest labor establishes a valuable business could forfeit it all if, in the course of his business, he is mixed up in a single fraudulent scheme."); United States v. Huber, 603 F.2d 387, 397 (2d Cir. 1979) ("We do not say that no forfeiture sanction may ever be so harsh as to violate the Eighth Amendment."), cert. denied, 445 U.S. 927 (1980).

189821 F.2d 1365 (9th Cir. 1987).

100 See id. at 1386.

101817 F.2d 1409 (9th Cir. 1987).

${ }^{162}$ Littlefield, 821 F.2d at 1368 (citing Busher, 817 F.2d at 1413-14). 
the Constitution."163

The defendant in Busher owned ninety-two percent of a corporation that carried out construction work for the Department of Defense. He was convicted under RICO for submitting false claims to the government ${ }^{164}$ and was consequently forced to forfeit his entire interest in the corporation, in another corporation used as a fictitious subcontractor, and in real estate owned by the second corporation. ${ }^{165}$

After noting that the RICO forfeiture provisions were intended to be broadly construed, ${ }^{168}$ the Busher court noted that RICO also covers "an extraordinarily broad range of activities. Forfeiture under RICO can . . . result from very serious, as well as from more trivial, violations of the law."167 Thus, "[s]ince RICO's forfeiture provision is quite literally without limitation, it may well exceed constitutional bounds in any particular case."188 This concern is not as warranted when property is forfeited under the Comprehensive Forfeiture Act, in which Congress declared that drug-related felonies, which are not trivial offenses, merit forfeiture. Nevertheless, any punishment has the potential to constitute an eighth amendment violation.

Busher relied heavily on the Supreme Court's decision in Solem $v$. $\mathrm{Helm},{ }^{\mathbf{1 6 9}}$ in which the Court held that the Constitution prohibits punishments that are disproportionate to the crime. ${ }^{170}$ In Solem, the defendant had already been convicted of six nonviolent felonies ${ }^{171}$ when he was convicted of uttering a "no account" check for $\$ 100 .{ }^{172} \mathrm{Al}-$ though the maximum punishment for this offense was five years imprisonment and a $\$ 5000$ fine, he was sentenced to life imprisonment without parole under the South Dakota recidivist statute. ${ }^{173}$ The Court concluded "that his sentence is significantly disproportionate to his

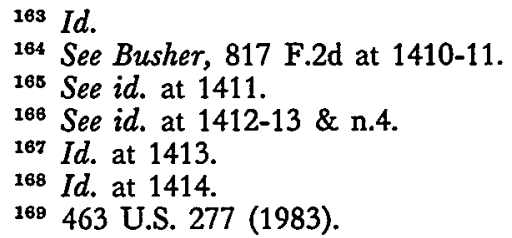

170 See id. at 290 ("We hold as a matter of principle that a criminal sentence must be proportionate to the crime for which the defendant has been convicted."); see also id. at 284 ("The final clause [prohibiting cruel and unusual punishments] prohibits not only barbaric punishments, but also sentences that are disproportionate to the crime committed."); Busher, 817 F.2d at 1414 (discussing Solem); id. at 1415 ("The eighth amendment prohibits only those forfeitures that, in light of all the relevant circumstances, are grossly disproportionate to the offense committed.").

171 The nonviolent felonies included three convictions for third-degree burglary and one conviction each for obtaining money under false pretenses, grand larceny, and third-offense driving while intoxicated. See Solem, 463 U.S. at 279-80.

172 See id. at $279-81$.

173 See id. at 281-82. 
crime, and is therefore prohibited by the Eighth Amendment."174

After tracing the history of proportional punishment in England, ${ }^{175}$ the Court stated that "[w]hen the Framers of the Eighth Amendment adopted the language of the English Bill of Rights, they also adopted the English principle of proportionality."176 It then noted that this principle applied to imprisonment as well as the "parallel limitations' on bail, fines and other punishments."177 The Court noted, however, that " [o]utside the context of capital punishment, successful challenges to the proportionality of particular sentences [will be] exceedingly rare." "178 Although "[ $t]$ his does not mean . . . that proportionality analysis is entirely inapplicable in noncapital cases" or, presumably, in cases not involving imprisonment, the Court directed that "[r]eviewing courts, of course, should grant substantial deference to the broad authority that legislatures necessarily possess in determining the types and limits of punishments for crimes."179

With this precedent in mind, the Busher court ordered the district court to weigh eighth amendment considerations according to a test derived from Solem. ${ }^{180}$ The most significant element of the test required that the district court consider the gravity of the offense, examining both the harm suffered by the victim and the defendant's culpability. ${ }^{181}$ An assessment of harm was to take into account "its magnitude: the dollar volume of the loss caused, whether physical harm to persons was inflicted, threatened or risked, or whether the crime has severe collateral consequences, e.g., drug addiction."182

174 Id. at 303.

170 See id. at 284-85.

${ }^{178} I d$. at $285-86$. The Court then stated that "[t]he constitutional principle of proportionality has been recognized explicitly in this Court for almost a century." Id. at 286.

177 Id. at 288-89 (citing Ingraham v. Wright, 430 U.S. 651, 664 (1977)).

${ }^{178} I d$. at 289-90 (quoting Rummel v. Estelle, 445 U.S. 263, 272 (1980)) (emphasis added by the Solem Court).

${ }^{178} \mathrm{Id}$. at 290.

180 See Busher, 817 F.2d at 1415.

181 See id. at 1415; see also Solem, 463 U.S. at 290-94 (discussing the objective criteria courts should use in conducting a proportionality analysis under the eighth amendment). The Busher court also directed the district court to consider "sentences imposed for other offenses in the federal system" and "sentences imposed for the same or similar offenses in other jurisdictions." Busher, 817 F.2d at 1415; see also Solem, 463 U.S. at 291-92 (same). Although these latter tests are not directly applicable to the forfeiture provisions, they are analogous to comparing section 853 forfeiture with the RICO and civil forfeiture provisions.

${ }_{182}$ Busher, 817 F.2d at 1415 (citing Solem, 463 U.S. at 293). To this list of factors the court in Littlefield added some potentially "relevant considerations, including the value of the illegal drugs cultivated on the property, and the nexus between the portion of the property actually used to grow the marijuana plants and the rest of the land." Littlefield, 821 F.2d at 1368. The nexus standard suggested by the Littlefield 
These concerns demonstrate that there should rarely be an eighth amendment problem with forfeiture under section 853. That Congress has enacted special laws, including forfeiture provisions, to deal with drug-related crimes indicates the seriousness with which these crimes are regarded. Drug trafficking has not only the serious collateral effect of drug abuse, ${ }^{\mathbf{1 8 3}}$ but drug abuse in turn may be a factor in most other serious crimes. ${ }^{184}$ Congress has found that traditional punishments have not hampered the enormously lucrative drug trade, and consequently it has emphasized forfeitures. ${ }^{188} \mathrm{It}$ is therefore difficult to conceive of circumstances under which section 853 forfeiture would violate the eighth amendment rights of a drug trafficker, ${ }^{186}$ especially given the Supreme

court undercuts its own decision, however, because examining the nexus between the property and the crime is the method for determining proportional forfeiture. To carry out the intent of Congress, it is sufficient for forfeiture of the entire parcel of real property that a drug felony occurred that was facilitated by, or required the use of, the real property.

A nexus standard was also proposed by the Busher court, which required examination of the degree to which the enterprise is infected by criminal conduct. See Busher, 817 F.2d at 1415 . Whether or not a "degree of infection" standard should be applied to RICO violations, it certainly should not be applied to forfeiture of real property under section 853. Real property is not an abstract concept that is as easily manipulated as an "enterprise", $c f$. United States v. Horak, 833 F.2d 1235, 1251 (7th Cir. 1987) (discussing potential "prosecutorial caprice in the choice of enterprise"), and thus its forfeiture would not require the same degree of scrutiny. Similarly, the offenses required for forfeiture under section 853 are all drug-related, and Congress has expressed specific concern with such crimes.

183 "Drug abuse in the United States is a problem of ever-increasing concern, and appears to be approaching epidemic proportions." H.R. REP. No. 1444, supra note 2 , at 6, reprinted in 1970 U.S. Code CoNG. \& ADMIN. News at 4572.

${ }_{184}$ See, e.g., N.Y. Times, Jan. 22, 1988, at A1, col. 6 (reporting a Justice Department study indicating that from "[h]alf to three-fourths of the men arrested for serious crimes in 12 major cities tested positive for the recent use of illicit drugs").

185 See S. REP. No. 225, supra note 4, at 191, reprinted in 1984 U.S. CoDE Cong. \& Admin. News at 3374 ("Today, few in the Congress or the law enforcement community fail to recognize that the traditional criminal sanctions of fine and imprisonment are inadequate to deter or punish the enormously profitable trade in dangerous drugs which, with its inevitable attendant violence, is plaguing the country. Clearly, if law enforcement efforts to combat racketeering and drug trafficking are to be successful, they must include an attack on the economic aspects of these crimes. Forfeiture is the mechanism through which such an attack may be made.").

${ }^{186}$ Confining application of these forfeiture provisions principally to professional criminals, as Congress seems to have intended, would answer the questions posed by those concerned with the effects of harsh forfeitures on individuals who, for example, have one or two marijuana plants for home use. See Sinoway, Seizures of Houses and Real Property Under Marijuana Forfeiture Laws, 14 SEARCH \& SEIzURE L. REP. $113,113,118$ (1987). Interestingly, Sinoway, the attorney for several of the defendants in Anderson I, the district court case preceding Littlefield, notes that in that case the government pursued forfeiture only in the case of Littlefield, who was growing more than 700 marijuana plants, but not against the other defendants, who he says were growing the plants only for personal use. See id. at 118-19. This approach avoids any eighth amendment violations. A Justice Department publication on forfeiture under the RICO and CCE forfeiture statutes states that "[a]11 RICO and CCE prosecutions re- 
Court's directive that "[r]eviewing courts, of course, should grant substantial deference to the broad authority that legislatures necessarily possess in determining the types and limits of punishments for crimes." "187 Given the seriousness of drug crimes as recognized by Congress, this "substantial deference" should be almost insurmountable.

There is a reason for regarding a section 853 forfeiture as not only an unlikely basis for an eighth amendment violation, but also an unwarranted one. It would seem perverse to allow small-time drug dealers to escape real property forfeiture by requiring that their crime be of great magnitude; to do so would defeat Congress's aim in enacting section 853 by allowing them to resume or even increase their activities after conviction with their economic base intact. The amount exacted to prevent future criminal activities in the drug trade should be allowed to be greater than an amount proportional to the initial wrongdoing.

\section{Conclusion}

On the basis of the analysis presented here, section 853 should be interpreted as requiring the forfeiture of entire parcels of property involved in drug-related crimes. The language of the provision makes the most sense when read in this light, ${ }^{188}$ and the legislative history of the original act and its amendment clarify any ambiguity in the statute. ${ }^{189}$ Comparison with the analogous forfeiture statute in $\mathrm{RICO}^{\mathbf{1 8 0}}$ and the civil forfeiture provision in Title $21^{191}$ leads to the same conclusion. Furthermore, eighth amendment considerations should rarely constrain courts from imposing even seemingly harsh forfeitures upon drug traffickers. ${ }^{182}$ Congress has recognized the dangers of drug abuse; the violence ${ }^{193}$ and corruption ${ }^{194}$ that accompany drug trafficking should lend a sense of urgency to courts handling forfeitures under the Comprehen-

quire the authorization of the Criminal Division." D. SMITH \& E. WEINER, GRIMINAL ForfeItures Under THE RICO and Continuing Griminal EnTERPRise STatUTES 2 (1980). "One of the purposes of Criminal Division review of all RICO [and CCE] prosecutions is to prevent any Eighth Amendment questions from arising." $I d$. at 21 n.20. Thus, although cases that violate the eighth amendment conceivably could arise, as a practical matter, prosecutorial discretion should weed out most violations.

${ }^{187}$ Solem, 463 U.S. at 290.

188 See supra notes 30-66 and accompanying text.

189 See supra notes 67-85 and accompanying text.

180 See supra notes 86-118 and accompanying text.

101 See supra note $119-56$ and accompanying text.

102 See supra notes 157-87 and accompanying text.

${ }^{103}$ See, e.g., N.Y. Times, Mar. 8, 1988, at B1, col. 6 (describing the rapidly escalating violence that characterizes trafficking in crack).

${ }_{104}$ See, e.g., N.Y. Times, Apr. 11, 1988, at A1, col. 5 (describing corruption in the criminal justice system brought on by the wealth and power of the drug trade). 
sive Forfeiture Act. To paraphrase the Second Circuit slightly: "It has been suggested that on the basis of this [Comment], the Government may be encouraged to seize more [real property] of drug traffickers. So be it."195

195 United States v. One 1974 Cadillac Eldorado Sedan, 548 F.2d 421, 427 (2d Cir. 1977). 